DOI: $10.15193 /$ zntj/2017/113/210

\author{
ALEKSANDRA SZYDLOWSKA, DOROTA ZIELIŃSKA
}

\title{
WPLYW DODATKU PRZYPRAWY Z SUSZONEJ KORY CYNAMONOWCA NA PRZEŻYWALNOŚĆ POTENCJALNIE PROBIOTYCZNYCH SZCZEPÓW BAKTERII W MUSACH DYNIOWO-JABŁKOWYCH I ICH JAKOŚĆ SENSORYCZNĄ
}

\author{
Streszczenie
}

Celem pracy było określenie wpływu dodatku cynamonu na przeżywalność dwóch potencjalnie probiotycznych szczepów bakterii: Lactobacillis rhamnosus K3, Lactobacillus brevis O24 oraz na jakość sensoryczną probiotycznych musów dyniowo-jabłkowych, przechowywanych w temp. $5{ }^{\circ} \mathrm{C}$ przez $21 \mathrm{dni}$. Zakres pracy obejmował produkcję probiotycznych musów dyniowo-jabłkowych w warunkach laboratoryjnych, oznaczenie liczby bakterii dwóch wymienionych szczepów, pomiar wartości pH oraz ocenę jakości sensorycznej produktów. Na podstawie przeprowadzonych badań stwierdzono istotny wpływ czasu przechowywania na liczbę bakterii Lactobacillis rhamnosus $\mathrm{K} 3$ i Lactobacillus brevis $\mathrm{O} 24 \mathrm{w}$ musach jabłkowo-dyniowych bez względu na poziom dodawanego cynamonu. Po upływie 7 dni przechowywania produktów w temp. $5{ }^{\circ} \mathrm{C}$ odnotowano statystycznie istotne zwiększenie liczby bakterii we wszystkich produktach z wyjątkiem musu zawierającego szczep bakterii Lactobacillis rhamnosus K3 i dodatek przyprawy na poziomie $3 \%$ przy jednoczesnym obniżeniu wartości $\mathrm{pH}$. Liczba bakterii potencjalnie probiotycznych szczepów Lactobacillis rhamnosus $\mathrm{K} 3$ oraz Lactobacillus brevis O24 utrzymywała się na wysokim poziomie, tj. powyżej $7 \mathrm{log}$ jtk/g produktu przez cały okres chłodniczego przechowywania musów dyniowo-jabłkowych. Dodatek sproszkowanego cynamonu na poziomie $6 \%$ wpływał na nieznaczne obniżenie ogólnej jakości sensorycznej musów. W produktach tych zaobserwowano wyższą intensywność odczucia smaku i zapachu innego, określanego jako „cynamonowy”. Przez cały okres przechowywania produkty charakteryzowały się wysoką jakością sensoryczną (średnia ogólna jakość sensoryczna wynosiła powyżej 6,3 j.u). Szczepy potencjalnie probiotycznych bakterii Lactobacillis rhamnosus K3 i Lactobacillus brevis $\mathrm{O} 24$ mogą być wykorzystywane do produkcji musów dyniowo-jabłkowych o akceptowanej jakości sensorycznej i odpowiedniej liczbie komórek bakterii warunkujących właściwości probiotyczne produktu finalnego.

Słowa kluczowe: szczepy probiotyczne, Lactobacillis rhamnosus K3, Lactobacillus brevis O24, musy dyniowo-jabłkowe, cynamon, jakość sensoryczna

Dr inż. A. Szydłowska, dr inż. D. Zielińska, Katedra Technologii Gastronomicznej i Higieny Żywności, Wydz. Nauk o Żywieniu Człowieka i Konsumpcji, Szkoła Główna Gospodarstwa Wiejskiego w Warszawie, ul. Nowoursynowska 159 C,02-776 Warszawa.Kontakt: aleksandra_szydlowska@sggw.pl 


\section{Wprowadzenie}

Możliwości wykorzystania bakterii fermentacji mlekowej (LAB) w technologii żywności odnoszą się do utrwalania żywności oraz do zwiększania asortymentu żywności funkcjonalnej, zwłaszcza produktów probiotycznych.

Dawniej przeprowadzano fermentację spontaniczną z udziałem mikroflory surowca, co stwarzało niebezpieczeństwo m.in. rozwoju dzikich szczepów bakterii, a także mogło prowadzić do obniżenia jakości sensorycznej czy psucia żywności. Obecnie w celu zapewnienia powtarzalnej jakości i bezpieczeństwa wyrobu finalnego stosuje się odpowiednie kultury starterowe, często o cechach probiotycznych [18].

$\mathrm{Na}$ etapie projektowania żywności probiotycznej istotnym czynnikiem jest dobór właściwej kultury starterowej, zdolnej do metabolizowania węglowodanowych składników surowców owocowych, zapewniającej właściwy i powtarzalny postęp procesu fermentacji [19]. Kolejnym ważnym czynnikiem jest wybór matrycy żywnościowej, stwarzającej możliwości rozwoju mikroflory probiotycznej oraz odpowiednich substancji kształtujących bukiet smakowo-zapachowy produktu finalnego. Należy uwzględnić nie tylko jakość tych substancji, ale również wpływ, jaki mogą wywierać na wzrost i przeżywalność probiotycznych szczepów bakterii bezpośrednio po procesie produkcji oraz podczas całego okresu przydatności do spożycia takiego wyrobu.

Zioła i przyprawy stanowią ważną grupę składników wykorzystywanych w projektowaniu żywności funkcjonalnej ze względu na zawartość różnych, biologicznie aktywnych związków oraz cenne właściwości sensoryczne. Cynamon jest jedną z najbardziej rozpowszechnionych przypraw na świecie, otrzymywaną z suszonej kory drzew rosnących głównie w południowej Azji (Cinnamomum zeylanicum) oraz w Azji południowo-wschodniej (Cinnamomum cassium). Głównym związkiem występującym w korze jest aldehyd cynamonowy. Cynamon zawiera również alkohol cynamonowy, kumaryny, kwasy fenolowe, terpeny, węglowodany i garbniki [13]. Występuje w formie sproszkowanej oraz w postaci zwiniętych w rulon kawałków, ma barwę rdzawą i dzięki zawartemu w nim olejkowi cynamonowemu ma silny aromat i charakterystyczny słodkawo-korzenny, lekko piekący smak. W technologii żywności cynamon jest dodawany do wielu produktów jako środek smakowo-zapachowy, m.in. do wypieków, napojów, potraw mięsnych, rybnych czy produktów mlecznych, zbożowych i owocowych. Stosuje się go także do gum do żucia ze względu na jego działanie odświeżające. Wykazuje także korzystne działanie prozdrowotne, m.in. przeciwzapalne, obniżające poziom cukru we krwi, wspomagające trawienie czy też wspomagające krzepnięcie krwi [7, 11].

W literaturze dostępne są tylko nieliczne doniesienia dotyczące wpływu cynamonu na przeżywalność probiotycznych szczepów bakterii LAB w żywności [3]. Projek- 
towanie żywności fermentowanej z udziałem nowych szczepów o właściwościach probiotycznych wpisuje się w aktualny trend badań nad żywnością funkcjonalną.

Celem pracy było określenie wpływu dodatku cynamonu na stabilność dwóch, potencjalnie probiotycznych szczepów bakterii: Lactobacillis rhamnosus K3 i Lactobacillus brevis $\mathrm{O} 24$ oraz na jakość sensoryczną probiotycznych musów dyniowojabłkowych.

\section{Material i metody badań}

Materiał do badań stanowiły musy jabłkowo-dyniowe z 3- i 6-procentowym dodatkiem cynamonu w postaci sproszkowanej, wyprodukowane $\mathrm{w}$ warunkach laboratoryjnych z następujących surowców:

- przecier dyniowy z odmiany dyni 'Melonowa Żółta', przygotowany według Szydłowskiej i Kołożyn-Krajewskiej [14],

- jabłka prażone (firmy „Marinex”, Polska) o deklarowanej przez producenta zawartości cukrów na poziomie $11 \mathrm{~g} / 100 \mathrm{~g}$ produktu),

- sacharoza (firmy „Diamant”, Polska),

- sproszkowany cynamon („Kamis”, Polska),

- szczepy bakterii potencjalnie probiotycznych Lactobacillis rhamnosus K3 i Lactobacillus brevis O24 pochodzące z kolekcji Zakładu Higieny i Zarządzania Jakością Żywności SGGW w Warszawie. Szczepy zostały wyizolowane z kiszonych ogórków i kapusty otrzymanych metodą tzw. spontanicznej fermentacji i wykazywały wybrane cechy probiotyczności (oporność na niskie pH, obecność soli żółci, zdolność adhezji oraz bezpieczeństwo) [20]. Szczepy hodowano na pożywce MRS (Merck, Niemcy) w temp. $37{ }^{\circ} \mathrm{C}$ przez $24 \mathrm{~h}$, a następnie używano do fermentacji przecieru dyniowego.

Próbki przecieru dyniowego zaszczepiano 24-godzinnymi hodowlami bakterii $L b$. rhamnosus $\mathrm{K} 3 \mathrm{i} \mathrm{Lb}$. brevis $\mathrm{O} 24 \mathrm{w}$ ilości $1 \%$ obj. produktu. Poziom początkowy wynosił $8 \log \mathrm{jtk} / \mathrm{ml}$. Fermentację przecieru dyniowego prowadzono w temp. $35{ }^{\circ} \mathrm{C}$ przez $24 \mathrm{~h} \mathrm{z}$ dodatkiem sacharozy na poziomie $8 \%$.

Musy dyniowo-jabłkowe produkowano w warunkach laboratoryjnych przez połączenie fermentowanego probiotycznego przecieru dyniowego z prażonymi jabłkami w stosunku objętościowym $1: 1$. Następnie dodawano sacharozę na poziomie $10 \%$ w stosunku do masy produktu i odpowiednio 3 i $6 \%$ cynamonu w postaci sproszkowanej. Wyprodukowane musy przechowywano w warunkach chłodniczych $\left(5^{\circ} \mathrm{C}\right)$ przez 21 dni.

Oznaczenie liczby bakterii kwasu mlekowego wykonywano metodą płytkową przez posiew na podłożu wybiórczym MRS (Biokar Diagnostic, Francja), zgodnie z normą PN-ISO: 15214:2002 [10]. 
Pomiar $\mathrm{pH}$ badanych produktów wykonywano zgodnie $\mathrm{z}$ normą PN-EN 1132:1999, z uwzględnieniem temperatury próbek, przy użyciu pH-metru CP-501 (Elmetron, Polska) [9].

Do oceny sensorycznej produktów zastosowano metodę ilościowej analizy opisowej QDA według normy PN-EN ISO 13299:2016-05 [6]. W celu opisania jakości sensorycznej produktów uwzględniono 12 wyróżników wytypowanych przez wyszkolony zespół oceniających (3 wyróżniki zapachu: dyniowy, jabłkowy, inny; 2 wyróżniki tekstury: gęstość, gładkość; 6 wyróżników smaku: dyniowy, słodki, kwaśny, jabłkowy, gorzki, inny). Oceny przeprowadzano z udziałem 10-osobowego zespołu pracowników Katedry Technologii Gastronomicznej i Higieny Żywności. Członkowie zespołu oceniającego zostali przeszkoleni w zakresie metodyki wykonywanych analiz oraz przebadani pod względem wrażliwości sensorycznej. Ocenę jakości sensorycznej powtarzano 3 razy w przypadku każdego okresu przechowywania. Podstawą wyników średnich było 30 ocen jednostkowych.

Analizę statystyczną przeprowadzono z wykorzystaniem programu Statistica 12 (StatSoft). Do oceny statystycznej wyników uzyskanych podczas pomiarów $\mathrm{pH}$ oraz oznaczenia liczby bakterii zastosowano jednoczynnikową analizę wariancji Anova $(\mathrm{p}<0,05)$. Do interpretacji wyników oceny sensorycznej przechowywanych produktów wykorzystano analizę składowych głównych PCA (Principal Component Analysis).

\section{Wyniki i dyskusja}

W badaniach własnych zastosowano dwa potencjalnie probiotyczne szczepy bakterii Lactobacillus rhamnosus $\mathrm{K} 3$ i Lactobacillus brevis $\mathrm{O} 24$ wyizolowane z żywności. W wyniku procesu fermentacji przecierów z dyni liczba bakterii, niezależnie od użytego szczepu, wzrosła o ok. 1 rząd logarytmiczny, co było skorelowane z obniżeniem wartości pH średnio do wartości 4,2.

Na rys. 1. i 2. przedstawiono zmiany liczby komórek bakterii Lactobacillus rhamnosus K3 i Lactobacillus brevis $\mathrm{O} 24$ oraz wartości $\mathrm{pH}$ w musach dyniowojabłkowych podczas przechowywania. Stwierdzono, że początkowa liczba bakterii w musach dyniowo-jabłkowych wynosiła $8,10 \div 9,01$ log jtk/g w zależności od użytego szczepu. Większą liczbę bakterii stwierdzono w przypadku próbek musów z dodatkiem szczepu Lactobacillus rhamnosus K3. Dodatkowo czynnikiem różnicującym produkty był poziom dodatku cynamonu. W przypadku obydwu zastosowanych szczepów niższą liczbę bakterii wykazano w próbkach $\mathrm{z}$ dodatkiem cynamonu na poziomie $6 \%$. 
3-procentowy dodatek cynamonu

Cinnamon added in the amount of $3 \%$

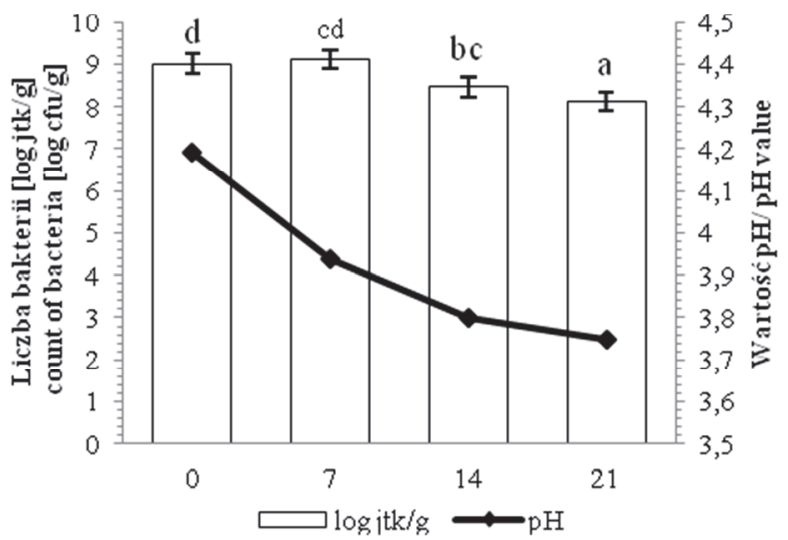

6-procentowy dodatek cynamonu

Cinnamon added in the amount of $6 \%$

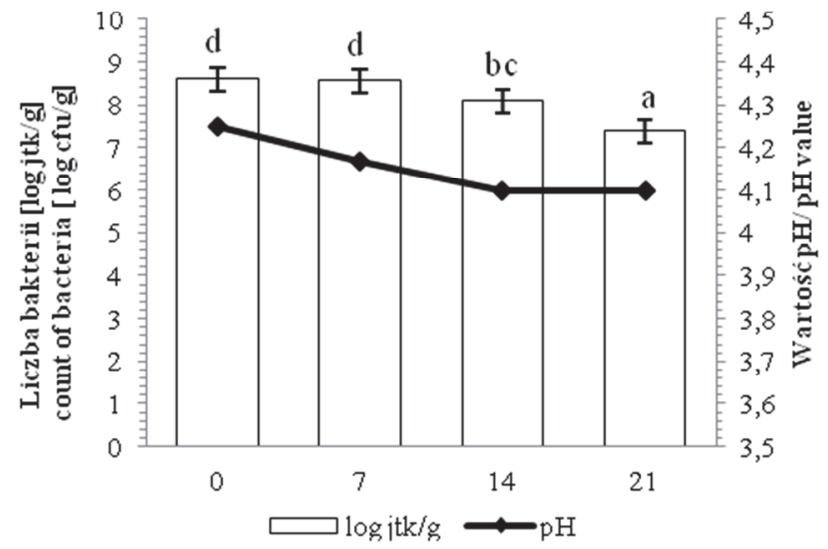

Objaśnienia / Explanatory notes:

$\mathrm{Na}$ rysunku przedstawiono wartości średnie (w postaci słupków) i odchylenia standardowe (w postaci odcinków) / Figure shows mean values (bars) and standard deviations (line segments); a, b, c, d - wartości średnie oznaczone tymi samymi literami nie różnią się między sobą statystycznie istotnie $(\mathrm{p}>0,05) /$ mean values denoted by the same letters don't differ statistically significantly $(\mathrm{p}>0.05)$.

Rys. 1. Zmiana liczby bakterii Lactobacillus rhamnosus $\mathrm{K} 3$ oraz wartości pH w musach dyniowojabłkowych podczas $21 \mathrm{dni}$ przechowywania w temp. $5{ }^{\circ} \mathrm{C}$

Fig. 1 Changes in count of bacteria of Lactobacillus rhamnosus $\mathrm{K} 3$ and in $\mathrm{pH}$ value in pumpkin-apple mousses during 21 days storage at temperature of $5{ }^{\circ} \mathrm{C}$ 
3-procentowy dodatek cynamonu

Cinnamon addend in the amount of $3 \%$

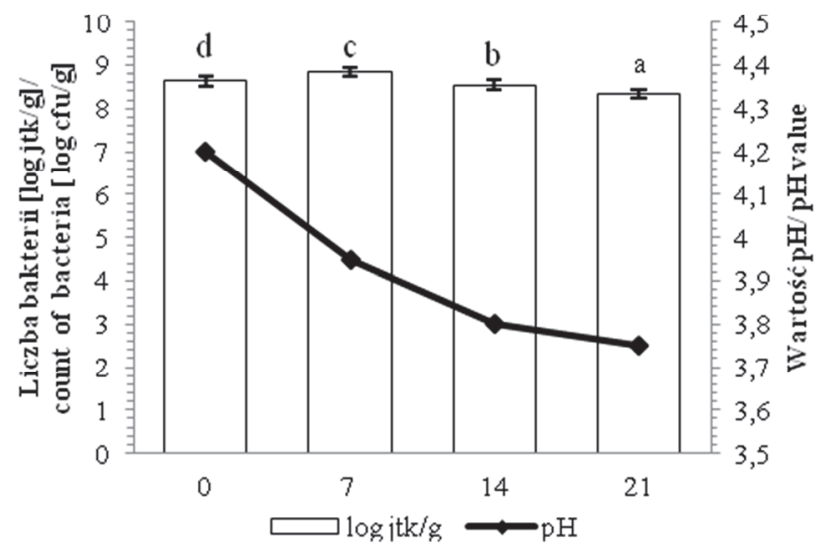

6-procentowy dodatek cynamonu

Cinnamon added in the amount of $6 \%$

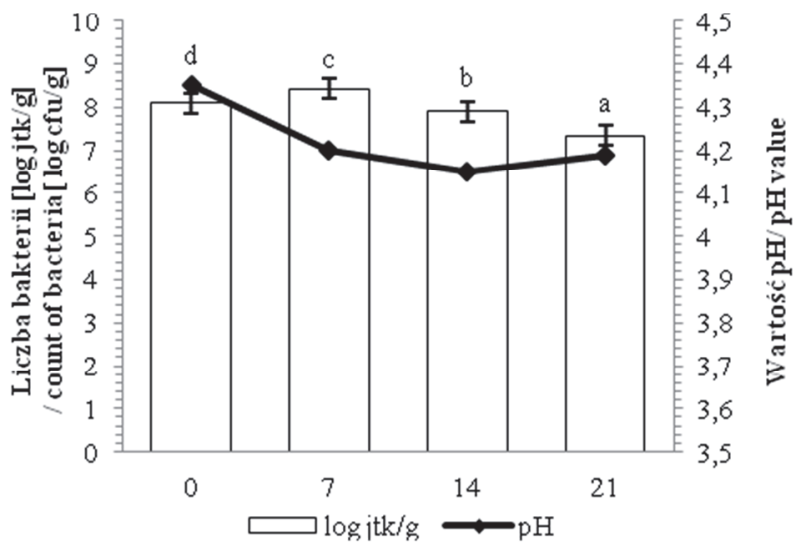

Objaśnienia jak pod rys. 1. / Explanatory notes as in Fig. 1.

Rys. 2. Zmiana liczby bakterii Lactobacillus brevis $\mathrm{O} 24$ oraz wartości $\mathrm{pH}$ w musach dyniowojabłkowych podczas 21 dni przechowywania w temp. $5^{\circ} \mathrm{C}$

Fig. 2. Changes in count of Lactobacillus brevis $\mathrm{O} 24$ bacteria and in $\mathrm{pH}$ value in pumpkin- apple mousses during 21 days storage at temperature of $5^{\circ} \mathrm{C}$

Po upływie 7 dni chłodniczego przechowywania statystycznie istotny wzrost liczby bakterii Lactobacillus brevis O24 zaobserwowano w musach dyniowo-jabłkowych (na rys. 2 zaznaczono słupkami) z 3- i 6-procentowym dodatkiem sproszkowanego cynamonu. $Z$ uwagi na zastosowany szczep oraz poziom dodatku przyprawy w ciągu kolejnych 14 dni liczba bakterii Lactobacillus ulegała istotnemu obniżeniu do poziomu 
$7,35 \div 8,34 \log$ jtk/g. Obniżenie liczby komórek bakterii w produkcie podczas przechowywania można przypisać kumulacji pewnych ilości kwasów organicznych produkowanych przez bakterie w wyniku ich aktywności i przeprowadzanego procesu fermentacji. Przeżywalność bakterii jest warunkowana zawartością cukrów w fermentowanym surowcu, udziałem suchej masy, zastosowaniem odpowiednich szczepów i/lub gatunków, czasem fermentacji, pH środowiska (produktu), warunkami przechowywania wyrobu finalnego, obecnością tlenu oraz dostępnością składników odżywczych w podłożu [19]. Także sam dodatek przypraw może ograniczać rozwój bakterii w produkcie ze względu na obecność substancji przeciwdrobnoustrojowych. Ważne jest, aby określić także wpływ tych dodatków na przeżywalność korzystnej mikroflory. W nielicznych badaniach wskazuje się na stabilność bakterii probiotycznych w produktach z dodatkiem niektórych przypraw, a nawet ich wzrost. Marhamatizadeh i wsp. [8] wykazali, że wraz ze zwiększeniem dodatku mięty do mleka probiotycznego i jogurtu nastąpił wzrost liczby bakterii Lactobacillus acidophilus i Bifidobacterium bifidum. Podobnie Yaghtin [17] stwierdził, że wraz ze wzrostem dodatku cynamonu wzrastała liczba bakterii probiotycznych w mleku i w jogurcie podczas chłodniczego przechowywania. Z kolei Romano i wsp. [12] do produkcji musów z kasztanów jadalnych użyli liofilizowanych form szczepu bakterii LAB - Lb. rhamnosus RBM526, który, tak jak szczepy zastosowane w badaniach własnych, został wyizolowany z żywności (z sera Parmigiano-Reggiano). W badaniach tych nie stwierdzono statystycznie istotnej zmiany liczby bakterii podczas 90 dni przechowywania produktów w temp. $15^{\circ} \mathrm{C}$. Po upływie 120 dni liczba bakterii wynosiła powyżej $7 \mathrm{log} \mathrm{jtk} / \mathrm{g}$. Wyniki badań własnych zdają się być zgodne z wynikami, jakie uzyskali Bakr Shori i Baba [1], którzy po 7 dniach przechowywania w temp. $4{ }^{\circ} \mathrm{C}$ odnotowali nieznaczny wzrost liczby bakterii Lactobacillus spp. w mleku krowim, wzbogaconym ziołowym ekstraktem wodnym Cinnamomum verum, natomiast po upływie 21 dni przechowywania w warunkach chłodniczych liczba ta uległa obniżeniu do poziomu ok. 6 log jtk/ml.

W badaniach własnych zmianom liczby bakterii w musach dyniowo-jabłkowych podczas przechowywania towarzyszyła zmiana ich wartości pH (na rys. 2. zaznaczono linią). Wraz ze wzrostem liczby bakterii po upływie 7 dni chłodniczego przechowywania produktów zaobserwowano statystycznie istotne obniżenie wartości $\mathrm{pH}$, średnio o ok. 0,25 jednostki. W miarę dalszego upływu czasu przechowywania wartość $\mathrm{pH}$ ulegała nieznacznemu obniżeniu. Zmiany te nie były jednak statystycznie istotne. Zmiany wartości $\mathrm{pH}$ były skorelowane $\mathrm{z}$ dodatkiem cynamonu. Zaobserwowano, że 6-procentowy dodatek cynamonu wpłynął na zahamowanie rozwoju i aktywności metabolicznej bakterii Lactobacillus, co skutkowało mniejszą produkcją kwasów organicznych i obserwowaną wyższą wartością $\mathrm{pH}$ w porównaniu $\mathrm{z}$ musem z 3-procentowym dodatkiem cynamonu (rys. 1 i 2). Podobnie Behrad i wsp. [3] stwierdzili obniżenie liczby bakterii $w$ jogurtach probiotycznych wyprodukowanych z udzia- 
łem kultur staterowych Lactobacillus acidophilus LA-5 i NCFM, Bifidobacterium Bb12, Lactobacillus casei LC-10, Streptococcus thermophilus Th-4 i z dodatkiem ekstraktu cynamonu na poziomie $6 \%$. Po upływie 21 dni przechowywania jogurtów w temp. $4{ }^{\circ} \mathrm{C}$ autorzy zaobserwowali istotne obniżenie wartości $\mathrm{pH}$ badanych prób. Natomiast Buritti i wsp. [4] po upływie 21 dni chłodniczego przechowywania nie odnotowali statystycznie istotnych zmian wartości $\mathrm{pH}$ oraz liczby bakterii Lactobacillus acidophilus w musach z owoców gujawy. Autorzy sugerują, że przy projektowaniu produktów probiotycznych niezwykle istotny jest wybór rodzaju surowców, w tym przypadku owoców, który może wpłynąć na przeżywalność probiotycznych szczepów bakterii. Stwierdzono także [2], że dodatek owocowych przecierów z mango i gujawy do jogurtu sojowego niekorzystnie wpłynął na liczbę bakterii probiotycznych w produkcie i tym samym utrudnił spełnienie tzw. kryterium probiotyczności. Zdecydowanie poprawił akceptację sensoryczną produktu.

W wyniku oceny sensorycznej wyprodukowanych musów jabłkowo-dyniowych oraz przeprowadzonej oceny statystycznej metodą PCA wyodrębniono 3 składowe główne, których suma wyjaśniała 70 \% całkowitej wariancji zmiennych. Suma wariancji 2 pierwszych składowych głównych wyjaśniała $57 \%$ wariancji zmiennych. Projekcję graficzną uzyskanych wyników przedstawiono na rys. 3 .

Pierwszą grupą jednorodną pod względem jakościowym były próbki świeżych musów jabłkowo-dyniowych oznaczone numerami 1 - 4. Produkty wysoko oceniono za zapach dyniowy, inny oraz za jakość ogólną, z wyczuwalną nutą smaku gorzkiego. Próbki z dodatkiem cynamonu na poziomie $6 \%$ (2 i 4) zostały najniżej ocenione pod względem ogólnej jakości sensorycznej spośród wszystkich produktów świeżych. $\mathrm{Na}$ drugim „biegunie jakościowym” zostały usytuowane próbki musów oznaczone numerami 4 - 8. To produkty oceniane po upływie 21 dni przechowywania. Ich jakość sensoryczna była niższa $\mathrm{w}$ porównaniu z próbkami produktów świeżych. Oceniający wskazywali w tym przypadku na większą intensywność odczucia smaku kwaśnego i innego, zidentyfikowanego jako „cynamonowy”. W przeprowadzonych badaniach własnych wykazano istotny wpływ dodatku cynamonu oraz czasu przechowywania na jakość sensoryczną musów. Zastosowane szczepy bakterii w niewielkim stopniu różnicowały jakość produktów.

Podobnych obserwacji dokonali Wilczyńska i wsp. [16], którzy wykazali, że dodatek cynamonu i kardamonu do miodów wpłynął znacząco na ich smak i zapach. Miód z dodatkiem cynamonu był najbardziej pożądanym produktem przez konsumentów. Dodatek przypraw nie miał jednak istotnego wpływu na strukturę i wygląd produktów. Również pozytywny wpływ cynamonu na jakość sensoryczną produktu na przykładzie czekolady gorzkiej odnotowali Dwijatmoko i wsp. [5]. Z kolei Vijayalakshmi i wsp. [15] poddali ocenie sensorycznej osiem rodzajów jogurtów z dodatkiem 


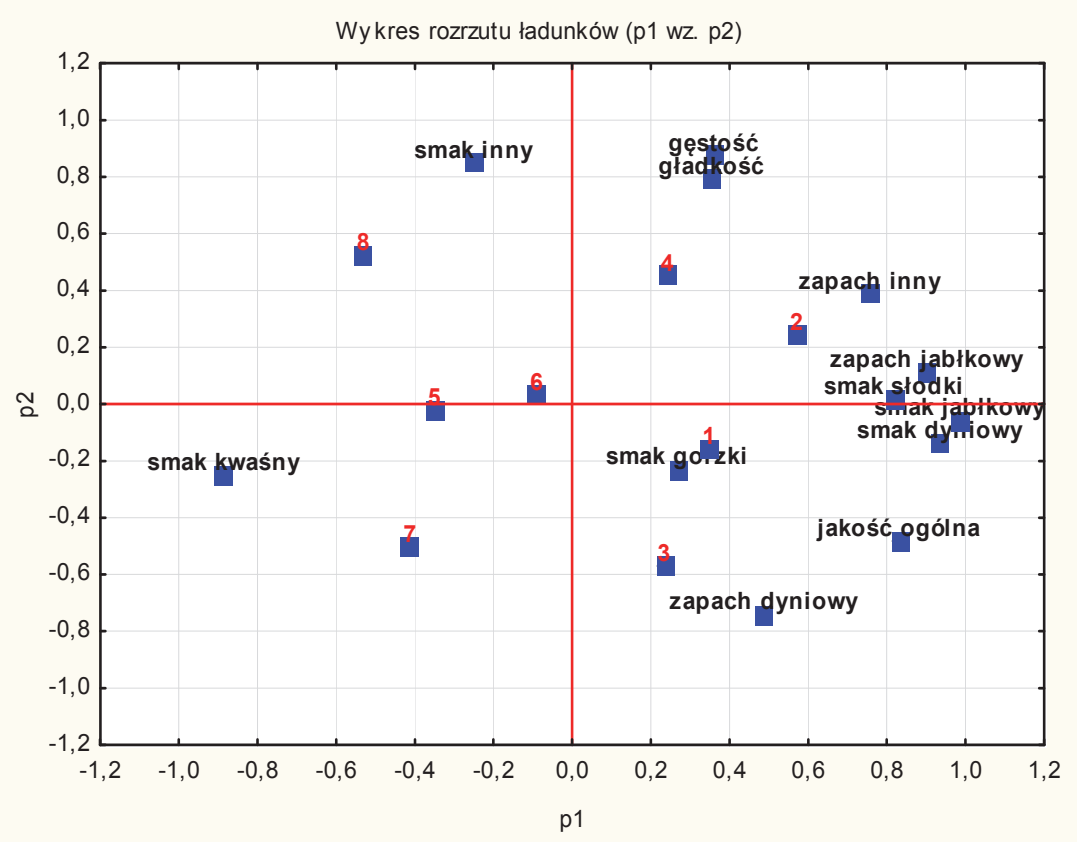

Objaśnienia / Explanatory notes:

gęstość / density; gładkość / smoothness; zapach dyniowy / pumpkin smell; zapach jabłkowy / apple smell; zapach inny / another smell; smak dyniowy / pumpkin taste; smak jabłkowy / apple taste; smak słodki / sweet taste; smak gorzki / bitter taste; smak kwaśny / sour taste, smak inny / another taste, jakość ogólna / total quality.

1. L. brevis O24, $3 \%$ dodatku cynamonu, świeże / L. brevis O24, $3 \%$ addition of cinnamon, fresh; 2. L. brevis O24, 6 \% dodatku cynamonu, świeże / L. brevis O24, $6 \%$ addition of cinnamon, fresh; 3. L. rhamnosus K3, $3 \%$ dodatku cynamonu, świeże / L. rhamnosus K3, $3 \%$ addition of cinnamon, fresh; 4 . $L$. rhamnosus K3, $6 \%$ dodatku cynamonu, świeże / L. rhamnosus K3, $6 \%$ addition of cinnamon, fresh; 5. L. brevis $\mathrm{O} 24,3 \%$ dodatku cynamonu, czas przech. 21 dni / L. brevis O24, $3 \%$ addition of cinnamon, 21 days of storage period; 6. L. brevis O24, $6 \%$ dodatku cynamonu, czas przech. 21 dni / L. brevis O24, $6 \%$ addition of cinnamon, 21 days of storage period; 7. L. rhamnosus $\mathrm{K} 3,3 \%$ dodatku cynamonu, czas przech. 21 dni / L. rhamnosus K3, 3 \% addition of cinnamon, 21 days of storage time; 8. L. rhamnosus $\mathrm{K} 3$, $6 \%$ dodatku cynamonu, czas przech. $21 \mathrm{dni} /$ L. rhamnosus K3, $6 \%$ addition of cinnamon, 21 days of storage time

Rys. 3. Graficzne przedstawienie wyników profilowania jakości musów dyniowo-jabłkowych poddanych analizie składowych głównych (PCA)

Fig. 3. Graphical presentation of quality profiling results of pumpkin-apple mousses analyzed by Principal Component Analysis (PCA)

przypraw w postaci ekstraktów: oleorezyn, tj. kardamonu, cynamonu i gałki muszkatołowej, z dodatkiem probiotycznych szczepów bakterii Lactobacillus acidophilus 5 (LA5) lub Bifidobacterium animalis ssp. lactis (Bb12). Najwyżej oceniono próbki $\mathrm{z}$ dodatkiem kardamonu (z LA5 lub Bb12). Badane jogurty probiotyczne zawierające 
przyprawy wykazywały dobre właściwości sensoryczne podczas 28 dni przechowywania w temp. $4{ }^{\circ} \mathrm{C}$. W przypadku badań własnych po 21 dniach przechowywania obserwowano natomiast obniżenie jakości sensorycznej musów owocowo-dyniowych, co może być związane ze specyfiką matrycy żywnościowej.

\section{Wnioski}

1. Dodatek sproszkowanego cynamonu na poziomie $6 \%$ wpłynął nieznacznie na obniżenie ogólnej jakości sensorycznej musów. W produktach tych odnotowano wyższą intensywność odczucia smaku i zapachu innego, określanego jako „cynamonowy".

2. Liczba bakterii Lactobacillis rhamnosus K3, Lactobacillus brevis $\mathrm{O} 24$ utrzymywała się na wysokim poziomie $>7 \mathrm{log} \mathrm{jtk} / \mathrm{g}$ produktu przez cały okres chłodniczego przechowywania.

3. Szczepy potencjalnie probiotycznych bakterii Lactobacillis rhamnosus K3 i Lactobacillus brevis $\mathrm{O} 24$ mogą być wykorzystywane do produkcji musów dyniowojabłkowych o akceptowanej jakości sensorycznej i odpowiedniej liczbie komórek bakterii warunkujących właściwości probiotyczne produktu finalnego.

\section{Literatura}

[1] Bakr Shori A., Baba A.S.: Viability of lactic acid bacteria and sensory evaluation in Cinnamomum verum and Allium sativum-bio-yogurts made from camel and cow milk. J. As. Arab. Univer. Basic Appl. Sci. 2012, 11 (1), 50-55.

[2] Bedani R., Diogo A.D.S., Rossi E.A., Saad S.M.I.: Tropical fruit pulps decreased probiotic survival to in vitro gastrointestinal stress in synbiotic soy yoghurt with okara during storage. LWT - Food Sci. Technol., 2014, 55 (2), 436-443.

[3] Behrad S., Yusof M.Y., Goh K.L., Baba A.S.: Manipulation of probiotics fermentation of yogurt by cinnamon and licorice effects on yogurt formation and inhibition of Helicobacter pylori growth in vitro. Int. J. Biol., Biomolec., Agric. Food Biotechnol. Eng., 2009, 3 (12), 563-567.

[4] Buriti F.C., Tiemy A., Komatsu R., Saad S.M.I.: Activity of passion fruit (Passiflora edulis) and guava (Psidium guajava) pulps on Lactobacillus acidophilus in refrigerated mousses. Braz. J. Microbiol., 2007, 38, 315-317.

[5] Dwijatmoko M.S., Praseptiagga D.R., Muhhamad D.R.A.: Effect of cinnamon essential oils addition in the sensory attributes of dark chocolate. Nusantara Bioscience, 2016, 8 (2), 301-305.

[6] PN-EN ISO 13299:2016-05. Analiza sensoryczna. Metodyka. Ogólne wytyczne ustalania profilu sensorycznego.

[7] Kędzia A., Ziółkowska-Klinkosz M., Kusiak A., Kochańska B., Kędzia A.W., Wojtaszek-Słomińska A.: Działanie in vitro olejku cynamonowego (Oleum cinnamomi) na grzyby drożdżopodobne. Postępy Fitoterapii, 2015, 1, 16-20.

[8] Marhamatizadeh M.H., Afrasiabi S., Rezazadeh S., Marhamati Z.: Effect of spearmint on the growth of Lactobacillus acidophilus $\mathrm{m}$ and Bifidobacterium bifidum in probiotic milk and yogurt. Afr. J. Food Sci., 2011, 5 (13), 747-753.

[9] PN-EN 1132:1999. Soki owocowe i warzywne. Oznaczanie pH.

[10] PN-ISO 15214:2002. Mikrobiologia żywności i pasz. Horyzontalna metoda oznaczania liczby mezofilnych bakterii fermentacji mlekowej. Metoda płytkowa w temperaturze 30 stopni C. 
[11] Rao P.V., Gan S.H.: Cinnamon: A multifaceted medicinal plant. Evid. Based Complem. Alternat. Med., 2014, \#642942, 1-12.

[12] Romano A., Blaiotta G., Di Cerbo A., Coppola R., Masi P., Aponte M.: Spray-dried chestnut extract containing Lactobacillus rhamnosus cells as novel ingredient for a probiotic chestnut mousse. J. Appl. Microb., 2014, 116 (6), 1632-1641.

[13] Singletary K.: Cinnamon. Overview of health benefits. Nutr. Today, 2008, 43 (6), 263-266.

[14] Szydłowska A., Kołożyn-Krajewska D.: Zastosowanie bakterii potencjalnie probiotycznych do fermentacji przecieru z dyni. Żywność. Nauka. Technologia. Jakość, 2010, 6 (73), 109-119.

[15] Illupapalayam V.V., Smith S.C., Gamlath S.: Consumer acceptability and antioxidant potential of probiotic-yogurt with spices. LWT - Food Sci. Technol., 2014, 55 (1), 255-262.

[16] Wilczyńska A., Newerli-Guz J., Szweda P.: Influence of the addition of selected spices on sensory quality and biological activity of honey. J. Food Qual., 2017, \#6963904, 1-7.

[17] Yaghtin A.R.: The Study of sinnamon effect on Lactobacillus acidophilus and Bifidobacterium bifidum growth in probiotic milk banana production. Doctors of veterinary medicine thesis. Islamic Azad University, 2009, p. 733.

[18] Zaręba D., Ziarno M.: Alternatywne probiotyczne napoje warzywne i owocowe. Bromat. Chem. Toksykol., 2011, XLIV (2), 160-168.

[19] Ziarno M., Zaręba D., Ścibisz I.: Przeżywalność probiotycznych bakterii fermentacji mlekowej w modelowych jogurtach owocowych. Bromat. Chem. Toksykol., 2011, XLIV (3), 645-649.

[20] Zielińska D., Rzepkowska A., Radawska A., Zieliński K.: In vitro screening of selected probiotic properties of Lactobacillus strains isolated from traditional fermented cabbage and cucumber. Curr. Microbiol., 2015, 70, 183-194.

\title{
EFFECT OF DRY CINNAMON BARK SPICE ADDITIVE ON VIABILITY OF POTENTIALLY PROBIOTIC BACTERIAL STRAINS IN PUMPKIN-APPLE MOUSSES AND ON SENSORY QUALITY THEREOF
}

\author{
S u m m a ry
}

The objective of the study was to determine the effect of cinnamon additive on the viability of two potentially probiotic bacterial strains: Lactobacillis rhamnosus $\mathrm{K} 3$ and Lactobacillus brevis 024 as well as on the sensory quality of probiotic pumpkin-apple mousses stored at $5{ }^{\circ} \mathrm{C}$ for 21 days. The scope of the study included the production of probiotic pumpkin-apple mousses under the laboratory conditions, the determination of the count of probiotic bacteria of the two above named strains, measuring $\mathrm{pH}$ value and evaluating changes in the sensory quality of products. Based on the analyses performed, it was found that the period time of storage had a significant effect on the count of Lactobacillis rhamnosus $\mathrm{K} 3$ and Lactobacillus brevis 024 in the pumpkin-apple mousses regardless of the level of cinnamon added. After 7 days of storing at $5{ }^{\circ} \mathrm{C}$, a statistically significant increase of $3 \%$ was reported in the number of bacteria in all the products analyzed except those containing the bacterial strain of Lactobacillis rhamnosus $\mathrm{K} 3$ and the cinnamon spice additive as was, at the same time, a decrease in the $\mathrm{pH}$ value. The count of potentially probiotic bacterial strains of Lactobacillis rhamnosus $\mathrm{K} 3$ and Lactobacillus brevis O24 remained at a high level, i.e. above $7 \mathrm{log} \mathrm{cfu} / \mathrm{g}$ of product during the entire time of refrigerated storage of pumpkin-apple mousse. The cinnamon powder added in the amount of $6 \%$ caused the overall sensory quality of the mousses to slightly decrease. It was proved that those products had a higher intensity of other taste and flavour that was described as "cinnamon". During the storage period, the products were characterized by a high sensory quality (overall mean sensory quality was above $6.3 \mathrm{~A}$.U.). The potentially probiotic strains of Lactobacillis rhamnosus $\mathrm{K} 3$ and Lactobacillus brevis $\mathrm{O} 24$ can be used to produce pumpkin-apple mousses with acceptable sensory quality and a suitable number of bacterial cells to determine the probiotic properties of the end product.

Key words: probiotic bacterial strains, Lactobacillis rhamnosus K3, Lactobacillus brevis O24 pumpkinapple mousses, cinnamon, sensory quality 